\title{
First instalment in resolution of the Banksia spinulosa complex (Proteaceae): B. neoanglica, a new species supported by phenetic analysis, ecology and geography
}

\author{
Margaret L. Stimpson', Peter H. Weston², Ian R.H. Telford', Jeremy J. Bruhl' \\ I Botany, School of Environmental and Rural Science and N.C.W. Beadle Herbarium, University of New En- \\ gland, Armidale NSW 2351 Australia 2 National Herbarium of New South Wales, The Royal Botanic Gardens \\ and Domain Trust, Mrs Macquaries Road, Sydney, NSW 2000, Australia
}

Corresponding author: JeremyJ.Bruhl (jbruhl@une.edu.au)

Academic editor: Hugo De Boer | Received 24 May 2012 | Accepted 25 July 2012 | Published 3 August 2012

Citation: Stimpson ML, Weston PH, Telford IRH, Bruhl JJ (2012) First instalment in resolution of the Banksia spinulosa complex (Proteaceae): B. neoanglica, a new species supported by phenetic analysis, ecology and geography. PhytoKeys 14 : 57-80. doi: 10.3897/phytokeys.14.3415

\begin{abstract}
Taxa in the Banksia spinulosa Sm. complex (Proteaceae) have populations with sympatric, parapatric and allopatric distributions and unclear or disputed boundaries. Our hypothesis is that under biological, phenetic and diagnosable species concepts that each of the currently named taxa within the B. spinulosa complex is a separate species. Based on specimens collected as part of this study, and data recorded from specimens in six Australian herbaria, complemented by phenetic analysis (semi-strong multidimensional scaling and UPGMA clustering) and a detailed morphological study, we investigated both morphological variation and geographic distribution in the B. spinulosa complex. All specimens used for this study are held at the N.C.W. Beadle Herbarium or the National Herbarium of New South Wales. In total 23 morphological characters (11 quantitative, five binary, and seven multistate characters) were analysed phenetically for 89 specimens. Ordination and cluster analysis resulted in individuals grouping strongly allowing recognition of distinct groups consistent with their recognition as separate species. Additional morphological analysis was completed on all specimens using leaf, floral, fruit and stem morphology, providing clear cut diagnosable groups and strong support for the recognition of B. spinulosa var. cunninghamii and B. spinulosa var. neoanglica as species.
\end{abstract}

\section{Keywords}

Banksia spinulosa, Banksia cunninghamii, Banksia neoanglica, species limits, phenetics, new species, floral and inflorescence morphology

Copyright Margaret L. Stimpson et al. This is an open access article distributed under the terms of the Creative Commons Attribution License 3.0 (CC-BY), which permits unrestricted use, distribution, and reproduction in any medium, provided the original author and source are credited. 


\section{Introduction}

Banksia is a moderately sized genus currently of 212 taxa; viz. 78 species, 9 subspecies and 11 varieties (see Collins et al. 2009), plus 114 species previously included under Dryandra (Mast and Thiele 2007). There are 16 named species of Banksia in the eastern states of Australia (Collins et al. 2009). Species of Banksia are often found in sclerophyllous, heathy shrublands on nutrient poor soils and have spectacular spike-like cylindrical or flattened, head-like conflorescences that are easily recognised (Mast et al. 2005). The growth habit in Banksia ranges from small prostrate woody mats to $25 \mathrm{~m}$ tall trees. Only one species occurs naturally outside Australia, Banksia dentata, which extends to Papua New Guinea, Irian Jaya and the Aru Islands (George 1981; Mast et al. 2002).

According to George's (1999) classification, the B. spinulosa complex has the broadest latitudinal, altitudinal and ecological amplitude of any species in the genus (Thiele and Ladiges 1996). The B. spinulosa complex consists of four taxa distributed from north-eastern Queensland to eastern Victoria along the coast and highlands. Banksia spinulosa var. spinulosa occupies both latitudinal extremes but is replaced along the coast between the Sunshine Coast area in south-eastern Queensland and the Hawkesbury River in central eastern New South Wales by B. spinulosa var. collina, which also has inland outliers west to the Carnarvon National Park area. Banksia spinulosa var. cunninghamii is mostly a montane taxon distributed mostly between the Hunter River in central eastern New South Wales and eastern Victoria, with a northern disjunction in the McPherson Range along the Queensland-New South Wales border. It is broadly sympatric with, and frequently co-occurs in mixed populations alongside B. spinulosa var. spinulosa between the northern Blue Mountains and the Moss Vale district. Banksia spinulosa var. neoanglica is also a montane taxon, distributed from the McPherson Range and along the eastern edge of the New England Tableland, New South Wales south to the Hanging Rock area. Banksia spinulosa var. neoanglica is parapatric with a montane variant currently attributed to B. spinulosa var. collina in the Daves Creek area, Lamington National Park; it is allopatric with other taxa in the complex.

Most herbaria follow George $(1981,1988,1999)$ in treating this complex as one species with four varieties, viz. $B$. spinulosa var. spinulosa, $B$. spinulosa var. collina, $B$. spinulosa var. cunninghamii, and B. spinulosa var. neoanglica. Flora of New South Wales (NSW) Online (1999 onwards) treats the B. spinulosa complex as comprising two species, each with two infraspecific taxa: Banksia spinulosa var. collina, B. spinulosa var. spinulosa, B. cunninghamii subsp. cunninghamii, and B. cunninghamii subsp. A (= $B$. spinulosa var. neoanglica), and this paper will use this treatment as a reference point. The primary reason for recognising two species was the broad sympatry of $B$. spinulosa var. spinulosa and $B$. cunninghamii subsp. cunninghamii. There appears to be no hybridisation between these two taxa, indicating that these two taxa are reproductively isolated from one another and are therefore different biological species (Harden 2002). 
These competing taxonomic treatments have created confusion, examples of which can be found in species lists for some National Parks in New South Wales (unpublished visitor brochures), which include B. spinulosa var. neoanglica and B. cunninghamii subsp. A as separate entities. Some herbaria also concurrently use two names for the same entity (see the Atlas of Living Australia). Current circumscriptions of the taxa within the B. spinulosa complex are based on intuitive assessment of observed morphological variation, rather than an explicit analysis of the morphological variation. Thiele and Ladiges (1996) conducted a cladistic analysis of the whole of Banksia using 92 qualitative characters and 14 morphometric characters in an attempt to clarify interspecific relationships and to provide a phylogenetic classification. As that was a genus-wide study, limited work was conducted on or within individual species.

The aims of this study were (1) to test and set the taxonomic status and circumscription of $B$. cunninghamii subsp. A; and (2) to search for novel diagnostic characters that could be used to distinguish individual taxa within the $B$. spinulosa complex (sensu George 1988).

\section{Materials and methods}

\section{Study material}

Although dried herbarium specimens were available for this study, it was considered necessary to collect fresh material to adequately investigate character homology though a detailed study of different developmental stages. Existing herbarium specimens were deficient in some developmental stages and often were not suitable for destructive sampling. We made collections from locations in New South Wales and Queensland encompassing the full geographic range of Banksia cunninghamii subsp. A. Vouchers have been lodged at NE and/or NSW (Table 1). Each site was visited twice; the first time in February to observe the development of the rachis, the second time in May to observe the flowering process. During both visits observations were made and vouchers prepared.

\section{Observations and microscopy}

Micromorphology was examined using Leica MZ8 and MZ9 stereomicroscopes fitted with eyepiece graticules. Images were taken using a Wild M400 photomacroscope fitted with a Nikon DS-5M-L1 Digital Sight Camera System. Exploratory scanning electron microscopy of styles was undertaken using air and silca gel-dried samples mounted on double-sided carbon tabs on aluminium stubs. Specimens were coated with gold in a Neocoater sputter coater and examined at $15 \mathrm{kV}$ using a Neoscope JCM-5000 bench-top SEM. 
Table I. Vouchers used in phenetic and morphological analysis of the B. spinulosa complex. Numbers in the OTU code are M. L. Stimpson collection numbers. Bcu = Banksia cunninghamii subsp. cunninghamii; $\mathrm{Bco}=B$. spinulosa var. collina $; \mathrm{Bn}=B$. cunninghamii subsp. $\mathrm{A} ; \mathrm{Bsp}=B$. spinulosa var. spinulosa; $\mathrm{B} s p ?=$ putative hybrid of B. spinulosa var. collina $\times$ B. spinulosa var. spinulosa. Abbreviations: NP = National Park; NSW = New South Wales; Qld = Queensland. Voucher codes are herbarium abbreviations following Thiers (continuously updated). All elements of the collections were available at NE and/or NSW during the study, replicates will be distributed.

\begin{tabular}{|c|c|c|}
\hline OTU Code & Location & Voucher \\
\hline BcuHW30 & Hassans Walls, Hartley Vale, NSW & NE, NSW \\
\hline BcuHW32 & Hassans Walls, Hartley Vale, NSW & NE, NSW \\
\hline BcuHW41 & Hassans Walls, Hartley Vale, NSW & NE, NSW \\
\hline BcuSR43a & Scenic Railway, Katoomba, NSW & NE, NSW \\
\hline BcuSR43b & Scenic Railway, Katoomba, NSW & NE, NSW \\
\hline BcuSR43c & Scenic Railway, Katoomba, NSW & NE, NSW \\
\hline BcuHW114 & Hassans Walls, Hartley Vale, NSW & NE, NSW \\
\hline BcuHW115 & Hassans Walls, Hartley Vale, NSW & BRI, NE, NSW \\
\hline BcuEL117 & Evans Lookout, Blue Mountains, NSW & BRI, NE, NSW \\
\hline BcuCF118 & Cataract Falls, Blue Mountains, NSW & NE, NSW \\
\hline BcuML119 & McMahons Lookout, Blue Mountains, NSW & NE, NSW \\
\hline BcuFF121 & Fitzroy Falls, E of Moss Vale, NSW & NE, NSW \\
\hline BcuFF128 & Fitzroy Falls, E of Moss Vale, NSW & NE, NSW \\
\hline BcuMW122 & Medway, W of Moss Vale, NSW & NE, NSW \\
\hline BcuMW123 & Medway, W of Moss Vale, NSW & BRI, NE, NSW \\
\hline BcuMW126 & Medway, W of Moss Vale, NSW & NE, NSW \\
\hline $\mathrm{B} \operatorname{coK} 25 \mathrm{a}$ & Kungala, NSW & NE \\
\hline BcoK25c & Kungala, NSW & $\mathrm{NE}$ \\
\hline BcoK60a & Kungala, NSW & NE, NSW \\
\hline BcoK60b & Kungala, NSW & $\mathrm{NE}$ \\
\hline BcoK60c & Kungala, NSW & NE, NSW \\
\hline BcoKR61 & Kremnos, NSW & NE \\
\hline BcoKR62 & Kremnos, NSW & NE, NSW \\
\hline BcoTG88 & Tarragindi, Brisbane, Qld & NE, NSW \\
\hline BcoDCK102 & Daves Creek track, Lamington NP, Qld & NE \\
\hline BcoDCK85 & Daves Creek track, Lamington NP, Qld & NE, NSW \\
\hline BcoDCK103 & Daves Creek track, Lamington NP, Qld & $\mathrm{NE}$ \\
\hline BcoMY93 & Mullaway, NSW & NE \\
\hline BnRN27a & Robinsons Knob Trail, New England NP, NSW & NE, NSW \\
\hline BnRN27b & Robinsons Knob Trail, New England NP, NSW & NE, NSW \\
\hline BnRN27c & Robinsons Knob Trail, New England NP, NSW & NE, NSW \\
\hline BnBP28a & Banksia Point, New England NP, NSW & $\mathrm{NE}$ \\
\hline $\mathrm{BnBP} 28 \mathrm{~b}$ & Banksia Point, New England NP, NSW & $\mathrm{NE}$ \\
\hline BnBP28c & Banksia Point, New England NP, NSW & NE, NSW \\
\hline BnNE39a & Point Lookout road, New England NP, NSW & $\mathrm{NE}$ \\
\hline BnNE39b & Point Lookout road, New England NP, NSW & NE, NSW \\
\hline BnNE39c & Point Lookout road, New England NP, NSW & NE, NSW \\
\hline BnDCK79 & Daves Creek track, Lamington NP, Qld & NE, NSW \\
\hline BnDCK80 & Daves Creek track, Lamington NP, Qld & NE, NSW \\
\hline BnDCK81 & Daves Creek track, Lamington NP, Qld & NE, NSW \\
\hline BnDCK82 & Daves Creek track, Lamington NP, Qld & NE \\
\hline
\end{tabular}




\begin{tabular}{|c|c|c|}
\hline OTU Code & Location & Voucher \\
\hline BnBP96 & Banksia Point, New England NP, NSW & BRI, NE, NSW \\
\hline BnTC97 & Tom's Cabin, New England NP, NSW & BRI, NE, NSW \\
\hline BnMM98 & Mount Mitchell, NSW & BRI, NE, NSW \\
\hline BnMM99 & Mount Mitchell, NSW & BRI, NE, NSW \\
\hline BnG100 & Girraween NP, Qld & BRI, NE, NSW \\
\hline BnG101 & Girraween NP, Qld & BRI, NE, NSW \\
\hline BnDCK104 & Daves Creek track, Lamington NP, Qld & $\mathrm{NE}$ \\
\hline BnDCK105 & Daves Creek track, Lamington, NP, Qld & NE, NSW \\
\hline BnBB106 & Boonoo Boonoo NP, Morgan's Gully, NSW & BRI, NE, NSW \\
\hline BnBB107 & Boonoo Boonoo NP, Morgan's Gully, NSW & NE, NSW \\
\hline BnBB108 & Boonoo Boonoo NP, Morgan's Gully, NSW & NE, NSW \\
\hline BnBB109 & Boonoo Boonoo NP, Cyprus Pine Camp, NSW & NE, NSW \\
\hline BnGR110 & Gibraltar Range NP, Mulligans Hut, NSW & BRI, NE, NSW \\
\hline BnGR111 & Gibraltar Range NP, Mulligans Hut, NSW & NE \\
\hline BnGR112 & Gibraltar Range NP, Mulligans Hut, NSW & BRI, NE, NSW \\
\hline BnGR113 & Gibraltar Range NP, Mulligans Hut, NSW & $\mathrm{NE}$ \\
\hline BspDC42 & Darling Causeway, Blue Mountains, NSW & NE, NSW \\
\hline BspHB44 & Hazelbrook, Blue Mountains, NSW & NE, NSW \\
\hline BspHB45 & Hazelbrook, Blue Mountains, NSW & NE, NSW \\
\hline BspJB46 & Jervis Bay, NSW & NE, NSW \\
\hline BspJB59 & Jervis Bay, NSW & NE, NSW \\
\hline BspML120 & McMahons Lookout, Blue Mountains, NSW & NE, NSW \\
\hline BspFF127 & Fitzroy Falls, E of Moss Vale, NSW & NE, NSW \\
\hline BspMW129 & Medway, W of Moss vale, NSW & NE, NSW \\
\hline BspML130 & McMahons Lookout, Blue Mountains, NSW & NE, NSW \\
\hline BspEL131 & Evans Lookout, Blue Mountains, NSW & NE \\
\hline BspCF132 & Cataract Falls, Blue Mountains, NSW & NE, NSW \\
\hline Bsp?BU36 & Bouddi NP, NSW & NE, NSW \\
\hline Bsp?BU37 & Bouddi NP, NSW & NE \\
\hline Bsp?BU38 & Bouddi NP, NSW & NSW \\
\hline Bsp?CA52a & Calga, NSW & NSW \\
\hline Bsp?CA52b & Calga, NSW & NE, NSW \\
\hline Bsp?CA52c & Calga, NSW & NE, NSW \\
\hline Bsp?CA53a & Calga, NSW & NE, NSW \\
\hline Bsp?CA53b & Calga, NSW & NE, NSW \\
\hline Bsp?CA53c & Calga, NSW & NE, NSW \\
\hline Bsp?M54a & Morisset, NSW & NE, NSW \\
\hline Bsp?M54b & Morisset, NSW & NE, NSW \\
\hline Bsp?M54c & Morisset, NSW & BRI, NE, NSW \\
\hline Bsp?RM66 & Morisset, NSW & NE, NSW \\
\hline Bsp?YM67 & Morisset, NSW & NE, NSW \\
\hline Bsp?JB124 & Jervis Bay, NSW & $\mathrm{NE}$ \\
\hline Bsp?MM86 & Mount Mee, Qld & $\mathrm{NE}$ \\
\hline Bsp?MM87 & Mount Mee, Qld & $\mathrm{NE}$ \\
\hline Bsp?GM89 & Glasshouse Mountains, Qld & $\mathrm{NE}$ \\
\hline Bsp?GM90 & Glasshouse Mountains, Qld & $\mathrm{NE}$ \\
\hline Bsp?GM91 & Glasshouse Mountains, Qld & $\mathrm{NE}$ \\
\hline Bsp?GM92 & Glasshouse Mountains, Qld & $\mathrm{NE}$ \\
\hline
\end{tabular}




\section{Phenetic analysis}

\section{Selection of characters}

The character list was primarily constructed to include leaf, floral, stem and fruit morphology. Assessment of descriptions of the taxa in the B. spinulosa complex (George 1981, 1988; Thiele and Ladiges 1996; Harden 2002) led to the selection of characters for the inclusion in the phenetic analysis. Additional characters were considered based on observed differences in the field (Table 2). Wherever possible, quantitative characters were used to reduce subjectivity and to avoid artefacts resulting from the conversion of continuous variables into categorical ones. Qualitative character states were scored as either 1 or 2. Quantitative characters for each OTU were the mean of up to 10 measurements where possible.

Colours, however, were treated as multistate characters to maximise accuracy and repeatability, which allowed for some natural variation, thus avoiding spurious over-

Table 2. Characters used for phenetic analysis for the Banksia spinulosa species complex

\begin{tabular}{l|l}
\hline No. & Character and states \\
\hline 1 & Quantitative characters \\
\hline 2 & Length of complete conflorescence including peduncle $\pm 1 \mathrm{~mm}$ \\
\hline 3 & Width of lamina at widest point excluding teeth $\pm 1 \mathrm{~mm}$ \\
\hline 4 & Length of lamina including mucro $\pm 1 \mathrm{~mm}$ \\
\hline 5 & Length from base of lamina to first tooth excluding mucro $\pm 1 \mathrm{~mm}$ \\
\hline 7 & Length of seed including wing $\pm 1 \mathrm{~mm}$ \\
\hline $17^{*}$ & Width of wing at widest point $\pm 1 \mathrm{~mm}$ \\
\hline 9 & Length of seed excluding wing $\pm 1 \mathrm{~mm}$ \\
\hline 10 & Lumber of floral pairs around circumference of conflorescence \\
\hline 12 & Circumference of complete infructescence $\pm 1 \mathrm{~mm}$ \\
\hline 11 & Lamina interveinal thickness when dry $\pm 0.05 \mathrm{~mm}$ \\
\hline $20^{*}$ & Binary characters \\
\hline $21^{*}$ & Lignotuber: $1=$ absent $2=$ present \\
\hline $22^{*}$ & Floral bract keel number: $1=12=2$ \\
\hline $23^{*}$ & Bistal bract margins: $1=$ plain $2=$ recurved \\
\hline & Bract apiculum: $1=$ absent $2=$ present $1=$ not incurved $2=$ incurved \\
\hline 8 & Multistate characters \\
\hline 13 & Lamina apex: $1=$ tridentate, $2=$ bidentate, $3=$ unidentate \\
\hline 14 & Colour of lamina adaxial surface when dry \\
\hline 15 & Colour of lamina abaxial surface when dry \\
\hline 16 & Colour of lamina adaxial surface prior to drying- \\
\hline $18^{*}$ & Colour of lamina abaxial surface prior to drying \\
\hline $19^{*}$ & Style colour pre anthesis \\
\hline$=$ RHS colours, see Table $3 .{ }^{*}=$ new characters; i.e. not previously used in studies of Banksia (cf. Thiele \\
and Ladiges 1996$).$ \\
\hline
\end{tabular}


precision (see below). Royal Horticultural Society (RHS) colours were used to compare adaxial and abaxial leaf surfaces prior to, and after drying, as well as styles before and after anthesis. Each RHS colour was allocated a number from 1-26 (Table 3).

All leaf measurements were taken from leaves in the middle of a branchlet, selected from the whorl of branchlets subtending a resting terminal bud or conflorescence; leaves were measured after drying. Conflorescence characters such as number of floral pairs were counted live on the plant. Infructescences were measured vertically with a steel ruler and the circumference was measured with a sewing tape measure.

Infructescences were placed on a gas burner for 1-3 min then left on brown paper for two days in a dry place. Seeds were extracted using a pair of forceps and measured under a stereomicroscope using a calibrated eyepiece graticule.

\section{Dataset}

A dataset (Appendix 1) was maintained in Microsoft Excel and exported to PATN v. 3 for Windows (Belbin and Collins 2006). The characters were range-standardised and a

Table 3. RHS colour codes used in phenetic analysis

\begin{tabular}{|c|c|c|}
\hline Colours & RHS colours & Coded RHS colours \\
\hline Green Group & $135 \mathrm{a}-\mathrm{d}$ & 1 \\
\hline Green Group & $137 \mathrm{a}-\mathrm{d}$ & 2 \\
\hline Yellow Green Group & $146 a-d$ & 3 \\
\hline Yellow Green Group & $147 \mathrm{a}-\mathrm{d}$ & 4 \\
\hline Greyed White Group & $156 a-$ & 5 \\
\hline Greyed White Group & $156 \mathrm{~b}-\mathrm{d}$ & 6 \\
\hline Greyed White Group & $157 \mathrm{a}-\mathrm{d}$ & 7 \\
\hline Greyed Green group & $190 a-c$ & 8 \\
\hline Greyed Green Group & $190 \mathrm{~d}$ & 9 \\
\hline Greyed Yellow Group & $160 \mathrm{a}$ & 10 \\
\hline Greyed Yellow Group & $162 a-d$ & 11 \\
\hline Yellow green group & $148 \mathrm{~d}$ & 12 \\
\hline Green White group & $157 \mathrm{~b}$ & 13 \\
\hline Red Purple Group & $59 a-d$ & 14 \\
\hline Red Purple Group & $61 \mathrm{a}-\mathrm{d}$ & 15 \\
\hline Black Group & $202 a-d$ & 16 \\
\hline Greyed Yellow group & $160 \mathrm{~b}-160 \mathrm{~d}$ & 17 \\
\hline Greyed Green Group & $191 \mathrm{a}-\mathrm{d}$ & 18 \\
\hline Greyed Green Group & $195 \mathrm{a}-\mathrm{d}$ & 19 \\
\hline Greyed Green Group & $196 a-d$ & 20 \\
\hline Green Group & $139 a-d$ & 21 \\
\hline Greyed Green Group & $198 \mathrm{a}-\mathrm{d}$ & 22 \\
\hline Yellow Green Group & $148 \mathrm{a}-\mathrm{d}$ & 23 \\
\hline Yellow Green Group & $145 a-d$ & 24 \\
\hline Yellow Green Group & $152 a-d$ & 25 \\
\hline Greyed Green Group & $198 a-d$ & 26 \\
\hline
\end{tabular}


distance matrix calculated using the Gower distance metric (Wills et al. 2000). Threedimensional ordination plots were generated from the distance matrix using semistrong hybrid multidimensional scaling (SSH MDS) with 100 random starts and 200 iterations to minimise stress. Flexible UPGMA (Beta-value $=-0.1$ ) phenograms, 3D ordination scatter plots, and correlation of characters with ordination pattern (PCC) were produced directly within PATN. The criteria for circumscribing distinct taxa were: (1) the OTUs representing the putative taxa formed discrete groups that did not overlap those of any other groups of OTUs in both cluster and ordination analysis and (2) the OTUs within these groups showed an amount of morphological heterogeneity similar to that of the other putative species in the B. spinulosa complex included in the analysis (Plunkett et al. 2009). In total 23 characters were used, 11 morphometric, five binary, seven multistate qualitatively coded morphological characters (Table 2).

\section{Diagnostic qualitative morphological characters}

\section{Conflorescences}

The conflorescences of all taxa in the $B$. spinulosa species complex consist of an elongate woody rachis that has three types of bracts. Below the base of the rachis on the short peduncle are the involucral bracts. The second type of bract is the common bract each of which subtends a flower pair on the conflorescence axis. The third type of bract, a smaller floral bract, subtends each flower in a pair (Johnson and Briggs 1975; George 1981; Thiele and Ladiges 1996). In the early stage of conflorescence development, flower pairs start to develop along the rachis basipetally. The flowers emerge from each side of the floral bracts and above and below each large common bract. Bracts and flower pairs are arranged in vertical columns on the rachis. This pattern is visually enhanced with the development of styles. The vertical striping pattern remains until the perianth and the styles have senesced or fallen from the rachis (George 1981; Thiele and Ladiges 1996; Collins et al. 2009).

\section{Structure of the perianth (floral pairs)}

The perianth segments or tepals in Banksia each consist of a limb and a claw (Thiele and Ladiges 1996). In Banksia and most other Proteaceae the perianth is made up of four tepals (Wrigley and Fagg 1989; Weston 2006).

\section{Structure of the style}

The conflorescences in the B. spinulosa complex have the appearance of being a particular colour, i.e. black, red, yellow orange, or purple. It is the styles that are most boldly coloured with red, black, green, yellow or purple pigment, not the limb and claw (George 
1981; Collins et al. 2009). All styles in the B. spinulosa species complex are hooked and extend up to $3 \mathrm{~mm}$ past the limb and claw just prior to anthesis. The distal part of the style is modified as a pollen presenter and the stigmatic cavity is located at the apex of the style. The style is released from the limb upon anthesis (Thiele and Ladiges 1996; Weston 2006). All styles in the B. spinulosa complex have similar surfaces. Scanning electron microscopy was performed on the style surfaces and no distinguishing features were found.

\section{Leaf morphology}

All taxa within the B. spinulosa complex have leaves that are scleromorphic in texture, discolourous, and linear in shape. The indumentum on the abaxial leaf surface is felted and the midvein is raised on the abaxial surface of all leaves in all taxa within the complex. Continuous variation was found in the colour of adaxial and abaxial leaf surfaces both within and between populations of all taxa within the B. spinulosa complex.

\section{Lignotubers}

The term lignotuber refers to a woody swelling which may take the form of an extensive subterranean lignotuber, basal lignotuber, or an above ground lignotuber (Mibus and Sedgley 2000). The development of a lignotuber is considered to have evolved repeatedly in different lineages in response to increased fire frequency (Whelan and York 1998).

\section{Results and discussion}

\section{Phenetic analysis}

Ordination (Figure 1) and clustering (Figure 2) of the data matrix found five distinct groups of OTUs in the B. spinulosa complex: corresponding to a priori names B. spinulosa var. collina sens. lat., B. spinulosa var. collina $\times$ B. spinulosa var. spinulosa from near the New South Wales locations of Morisset, Bouddi and Calga, B. spinulosa var. spinulosa, B. cunninghamii subsp. cunninghamii, B. cunninghamii subsp. A. The phenogram displays the same five groups of OTUs (Figure 2). Even when we reran the analyses excluding all the binary characters (Characters 11,20-23; ordination and phenogram not presented), the same five groups of OTUs were obtained, which, along with the very low stress value (Figure 1) indicate that the results are robust. Twelve of the 23 characters, including quantitative, binary and multistate characters had correlated more than $70 \%$ with the ordination (Table 4 ) indicating sound choice of characters, a broad base of evidence for the patterns obtained, and confidence in the results obtained.

The cluster of OTUs of B. spinulosa from Morisset, Bouddi and Calga (Table 1) is characterised by red styles, at Morisset and Bouddi and black styles at Calga, 


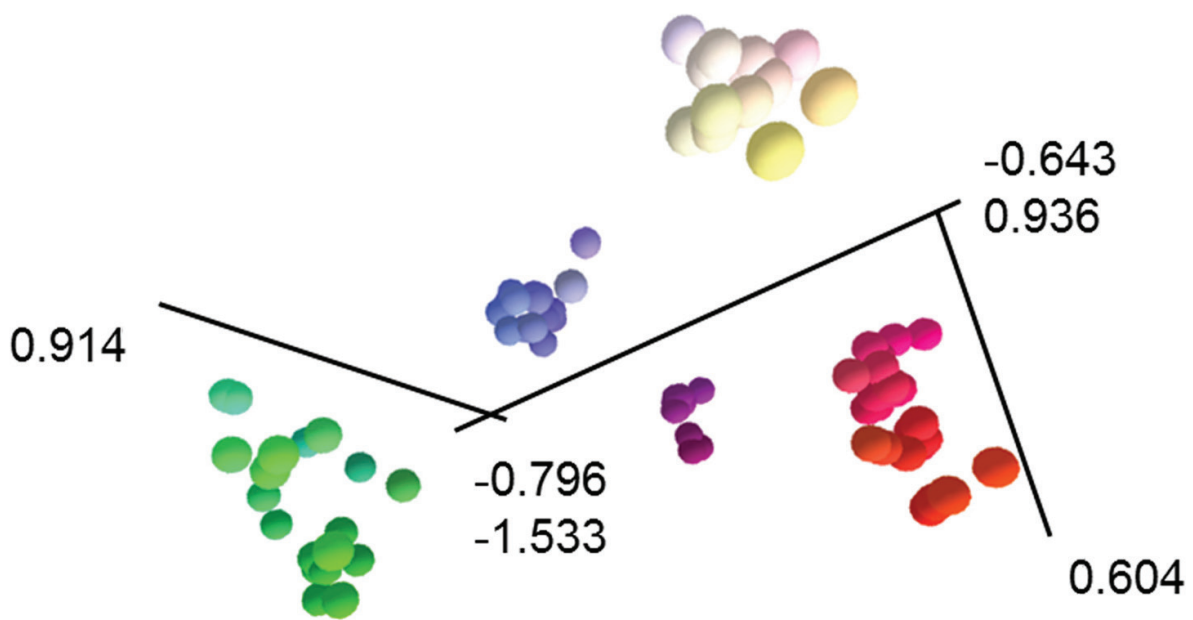

Figure I. 3D ordination from semi-strong multidimensional scaling of the Banksia spinulosa complex. From to left to right, $B$. spinulosa var. collina sens. lat., B. spinulosa from Morisset, Bouddi and Calga, $B$. spinulosa var. spinulosa, B. cunninghamii subsp. cunninghamii, B. cunninghamii subsp. A. Ordination stress $=0.795$. Size and colour of OTUs represents perspective. Ordination orientated to highlight separation of groups of OTUs. See Table 2 for characters and Appendix 1 for data.

Table 4. Principal component correlation (PCC) attributes and ordination vectors for ordination of the Banksia spinulosa complex. See Table 2 for Character numbers.

\begin{tabular}{c|c|c|c|c}
\hline Character & $\mathbf{X}$ & $\mathbf{Y}$ & $\mathbf{Z}$ & Correlation $\left(\mathbf{r}^{\mathbf{2}}\right)$ \\
\hline 21 & -0.115 & 0.983 & 0.146 & 0.978 \\
\hline 20 & 0.35 & 0.67 & 0.655 & 0.953 \\
\hline 14 & -0.254 & 0.695 & 0.672 & 0.938 \\
\hline 23 & -0.604 & 0.473 & -0.641 & 0.938 \\
\hline 18 & -0.464 & 0.482 & -0.743 & 0.929 \\
\hline 13 & 0.872 & 0.195 & -0.45 & 0.917 \\
\hline 22 & -0.787 & -0.327 & 0.523 & 0.893 \\
\hline 11 & -0.534 & -0.77 & -0.35 & 0.847 \\
\hline 8 & 0.767 & 0.269 & -0.583 & 0.84 \\
\hline 9 & -0.678 & 0.6 & -0.425 & 0.826 \\
\hline 10 & 0.146 & 0.72 & 0.679 & 0.766 \\
\hline 19 & -0.104 & 0.415 & -0.904 & 0.732 \\
\hline 3 & -0.477 & 0.868 & 0.141 & 0.581 \\
\hline 6 & 0.348 & 0.868 & -0.355 & 0.537 \\
\hline 2 & -0.339 & 0.662 & -0.669 & 0.454 \\
\hline 1 & -0.47 & 0.702 & -0.535 & 0.413 \\
\hline 16 & 0.174 & -0.25 & -0.952 & 0.391 \\
\hline 15 & 0.45 & 0.036 & -0.892 & 0.372 \\
\hline 12 & -0.326 & -0.601 & 0.729 & 0.308 \\
\hline 7 & 0.433 & 0.858 & -0.277 & 0.279 \\
\hline 5 & 0.005 & 0.635 & -0.772 & 0.193 \\
\hline 4 & 0.714 & 0.694 & 0.092 & 0.146 \\
\hline 17 & -0.614 & 0.567 & -0.549 & 0.123 \\
\hline & & & &
\end{tabular}




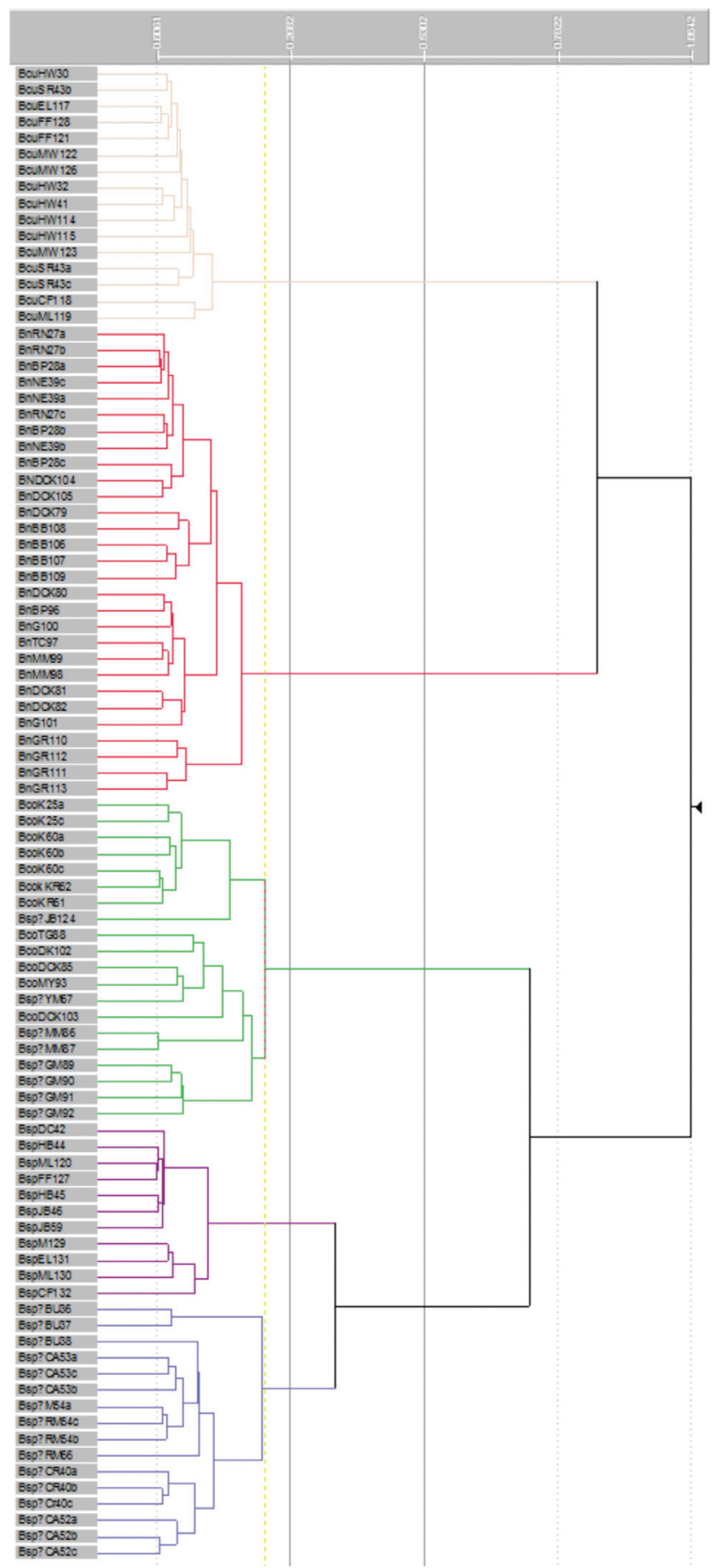

Figure 2. Flexible UPGMA phenogram of OTUs in the Banksia spinulosa complex. Major groups from top to bottom: $B$. cunninghamii subsp. cunninghamii, $B$. cunninghamii subsp. $A$, B. spinulosa var. collina sens. lat., B. spinulosa var. spinulosa, B. spinulosa from Morisset, Bouddi and Calga. See Table 2 for characters and Appendix 1 for data. 
multi-stemmed habit and occurs between the Hawkesbury River and Hunter Valley. Herbarium specimens from these locations have been determined by A.S. George and other botanists as "B. spinulosa var. collina $\times$ B. spinulosa var. spinulosa". George (1981) considered this group of OTUs to be an intergrade between B. spinulosa var. spinulosa and $B$. spinulosa var. collina. These populations do not fall in a position intermediate between B. spinulosa var. collina and B. spinulosa var. spinulosa in the ordination diagram, nor do they segregate into three clusters representing parental species and hybrids. There is thus no clear phenetic evidence of either an intergrade or a mixture of hybrids and parental species between the Hawkesbury River and Hunter Valley. The taxonomic status of these populations and their relationships to others remains unclear. This cluster of OTUs could represent a distinct species, but we will investigate this question and the broader relationship between B. spinulosa var. collina and B. spinulosa var. spinulosa further before making any formal taxonomic changes to these taxa.

Slight outliers in the B. spinulosa var. collina cluster represent some discontinuous morphological variation, which we also plan to investigate.

\section{Taxonomic inference}

Given the consistent clear cut groups in the ordination and cluster analysis across a broad geographic and morphological range of OTUs (Table 1), we propose the following taxonomic arrangement, which we use hereafter in this paper: recognising Banksia cunninghamii subsp. cunninghamii as $B$. cunninghamii sensu stricto; recognising $B$. spinulosa var. collina as $B$. collina sensu lato; recognising $B$. spinulosa var. spinulosa as B. spinulosa sensu stricto; formalising Banksia cunninghamii subsp. A at species rank under the name $B$. neoanglica. Although the OTUs of B. spinulosa from the Morisset and Bouddi populations could be considered to constitute a distinct species on the evidence we present here, we refrain from recognising these populations as a distinct taxon until we have more thoroughly tested the hypothesis that they are part of an extensive hybrid swarm and searched for any additional populations that might provide evidence for integradation between $B$. collina and B. spinulosa.

\section{Morphological analysis}

\section{Growth forms within the Banksia spinulosa species complex}

Banksia cunninghamii sensu stricto is a single-stemmed tree to $7 \mathrm{~m}$ tall, and is non-lignotuberous. Banksia spinulosa sensu stricto forms a multi-stemmed, rounded shrub to $3 \mathrm{~m}$ high. The lignotuber is subterranean. Banksia collina sensu lato is a multi-stemmed upright shrub to $3 \mathrm{~m}$ tall, with a subterranean lignotuber (Harden 2002; George 1981).

Banksia neoanglica has a variety of growth forms ranging from small rounded multistemmed shrubs to single-stemmed trees. The growth forms of $B$. neoanglica appear to 
be related to the degree of exposure of plants to fire. At sites where there have been no fires for more than 15 years, such as at Binna Burra, Lamington National Park, Queensland and some parts of Gibraltar Range National Park, New South Wales (Pers. Comm. Justin Kreis Ranger Glen Innes National Park), B. neoanglica is a single-stemmed tree and exhibits all the traits of an obligate seeder such as a greater infructescence load and spontaneous opening of the follicles. In the tree form, B. neoanglica has a slight swelling at the base of the trunk just below the soil or there are epicormic buds which often develop into branches, well above ground level, similar to those of some eucalypts (Burrows 2008). The multi-stemmed form has a substantial subterranean lignotuber and requires fire to open follicles and has a greatly reduced infructescence load.

\section{Individual adult morphological features}

Styles: The structure of the conflorescence, including perianth and styles is similar for all taxa in the $B$. spinulosa complex. Size, shape and colour of the individual parts of the conflorescence, however, differ considerably across the species. Style colour in the B. spinulosa complex varies depending on the proportions of chlorophyll (green), carotenoid (yellow to orange), anthoxanthin (yellow) and anthocyanin (red to purple) pigments that develop in them (Grotewold 2006). The style colour in B. neoanglica, B. spinulosa sensu stricto and B. cunninghamii sensu stricto usually grades from red to maroon to purple during conflorescence development, then the style becomes discolorous at anthesis, with the apex becoming dark purple to black. This is a consistent character within and between populations of three species in the Banksia spinulosa complex. The exception is B. collina sensu lato which has concolourous green styles both before and after anthesis. We found no black-styled $B$. collina sensu lato within the geographical range of this project.

The style apex in $B$. cunninghamii sensu stricto seems to have substantially more anthocyanin pigment than either $B$. spinulosa sensu stricto or $B$. neoanglica. In $B$. cunninghamii sensu stricto we observed that the style length is usually longer than either $B$. spinulosa sensu stricto or $B$. neoanglica and is a similar length to $B$. collina sensu lato. The black pigmentation of the styles of $B$. cunninghamii sensu stricto starts to develop one third of the way along the style above the ovary. In B. spinulosa sensu stricto and $B$. neoanglica the dark pigmentation in the style develops one half to two thirds of its length above the ovary. In all populations in the B. spinulosa complex with the exception of $B$. collina sensu lato we observed what appeared to be yellowstyled conflorescences. Upon closer inspection they are green styled and appear to have less chlorophyll in both the styles and leaves than is found in B. collina sensu lato which is also green-styled. Green styled variants are found in less than $2 \%$ of any one population except in B. collina. Polymorphism is a common trait in Proteaceae where, for example, $40 \%$ of all species of Protea exhibit variation in the bract, style and perianth colour (Carlson et al. 2010). It is often unclear whether these variants are transient mutant individuals or this feature is a persistent polymorphism (Carlson et al. 2010). In the case of the Banksia spinulosa complex, however, the variants 
comprise less than $2 \%$ of a population and were not found in every population; therefore it is unlikely to be persistent polymorphism.

Perianth colour: The colours of the perianth in the B. spinulosa complex vary according to their developmental stage and their exposure to sunlight. The perianth colours can vary within and between populations in all four of the species in the $B$. spinulosa complex. The factor that seems to have the most influence on the perianth colour in the early stages of development is exposure to sun, often mediated by the position of an conflorescence on the outside or inside branches of the plant or by shading from other plants. In B. spinulosa sensu stricto, B. collina and B. neoanglica, the conflorescences that are exposed to full sun tend to have orange or yellow perianths. Those that are exposed to a limited amount of sun tend to be green. The perianth colour of $B$. cunninghamii sensu stricto is diagnostic for the species. At maturity the perianth always has a distinct pink hue and this colouring continues through to anthesis. The pink hue does not vary between and within populations of B. cunninghamii sensu stricto, nor does exposure to full sun or full shade effect the colour of the perianth at maturity.

Common bracts: Common bracts have been mentioned in previous studies (Johnson and Briggs 1975; Thiele and Ladiges 1996; George 1981) but the bract surfaces had not been mentioned before this study or used to draw taxonomic conclusions. Close examination, especially at early stages of development, of the abaxial surface of the common (or flower pair) bracts found them to have differences in shape, texture, colour, and surface (Figure 3A-D) which covary in line with the entities recognised here (Figures 1-2) within the B. spinulosa complex. We will characterise these differences for use in future expanded phenetic analysis and description of taxa in Banksia. Floral bracts were not examined in detail in this study.

Involucral bracts: Involucral bracts appear to be taxonomically informative at the species level in the study group. The involucral bracts of $B$. cunninghamii sensu stricto are caudate with an abaxial 'spine' (Figure 4A). The involucral bracts in B. spinulosa sensu stricto (Figure $4 \mathrm{~B}$ ) are longer and more scleromorphic, with little or no hair and no external spine. In Banksia neoanglica (Figure 4C) these bracts are more hirsute without an external spine and in B. collina sensu lato (Figure 4D) the involucral bracts are shorter, have no external spine and limited hair. There are differences in the distal and proximal portions of the involucral bracts (Figure 4A-D) in each species that warrant further examination.

\section{Taxonomic conclusions}

The diversity of species concepts in the biological literature is an asset, not a liability when considering the Banksia spinulosa complex and are an integral part of biological theory. We have taken into account the co-varying morphological discontinuities, the phenetic species concept, geographical and ecological isolation and the biological species concept of reproductive isolation. The use of differing concepts has been useful in suggesting multiple lines of evidence for testing taxonomic boundaries in the Banksia spinulosa complex (cf. de Queiroz 2007). Clear taxonomic groups were obtained based 

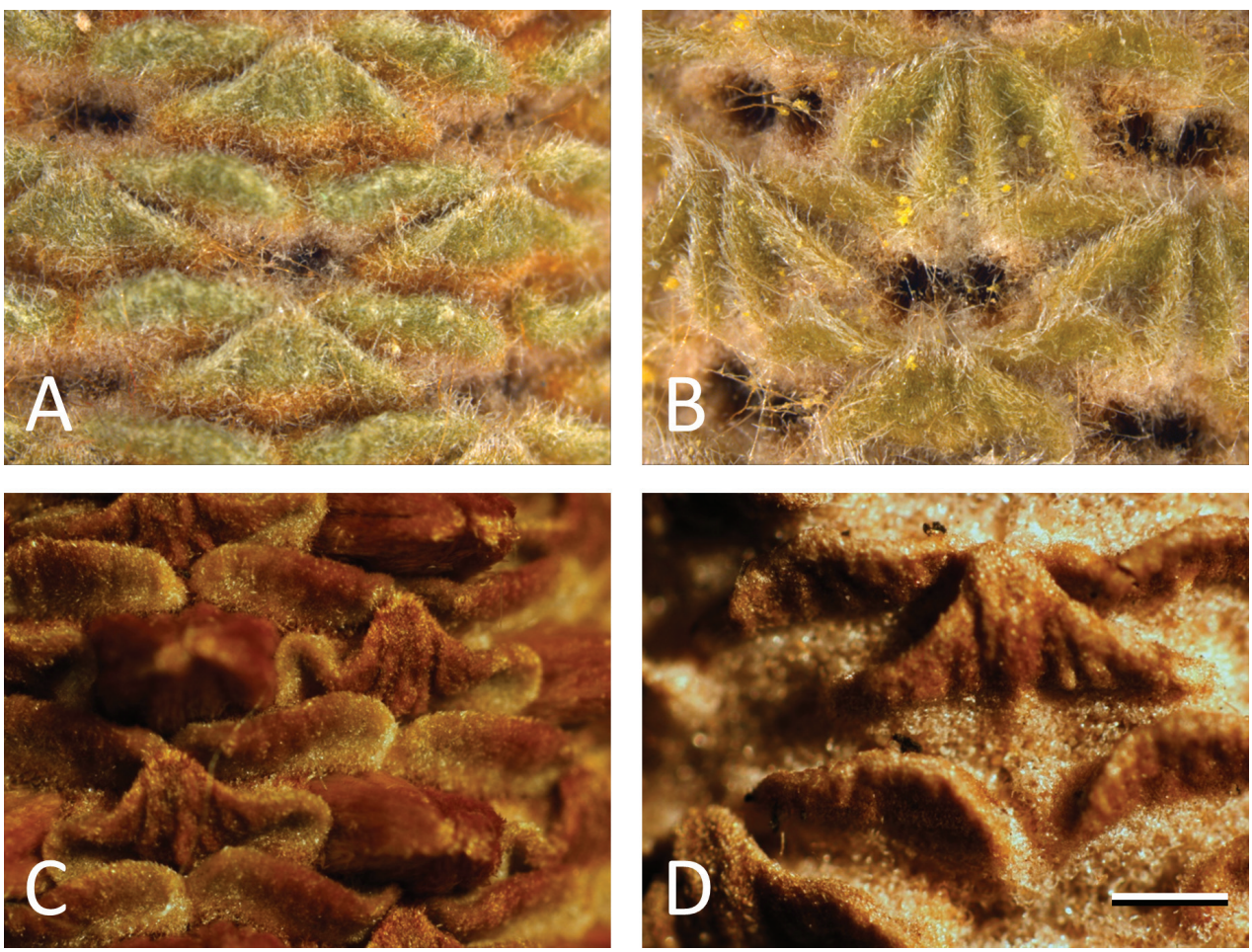

Figure 3. Common bracts on young conflorescences in the Banksia spinulosa species complex: $\mathbf{A} B$. neoanglica (M.L. Stimpson 98) B B. cunninghamii sensu stricto (M.L. Stimpson 122) C B. collina sensu lato (M.L. Stimpson 25A) D B. spinulosa sensu stricto. (M.L. Stimpson 120). Scale bar $=1 \mathrm{~mm}$.

on the results of the morphometric analyses and corroborated by new characters (cf. Thiele and Ladiges 1996) such as the abaxial surface of the common bract (Figure 3), the number of floral pairs around the circumference of the conflorescence and obvious differences in the involucral bracts (Figure 4A-D). Additionally, given the ecological isolation, reproductive isolation and morphometric differentiation of at least three of the taxa in the B. spinulosa complex, there is a compelling case to recognise Banksia spinulosa sensu stricto, Banksia cunninghamii sensu stricto and Banksia neoanglica as separate species (Table 5). Banksia collina sensu lato is considered heterogeneous and in need of further study, but is not readily confused with B. neoanglica. Similarly B. spinulosa from the Morisset, Bouddi and Calga requires further study but is distinct from B. neoanglica.

The geographic distribution of Banksia neoanglica falls within the biogeographic region known as the "Macpherson-Macleay Overlap" of Burbidge (1960), which is a biogeographically distinctive and rich area (Crisp et al. 1999) with many species of plants and invertebrates endemic to the area.

Banksia cunninghamii sensu stricto and $B$. neoanglica have often been misidentified because $B$. cunninghamii sensu stricto, on occasions, has a brown indumentum; $B$. neoanglica sometimes also exhibits browning on the abaxial leaf surface. This char- 

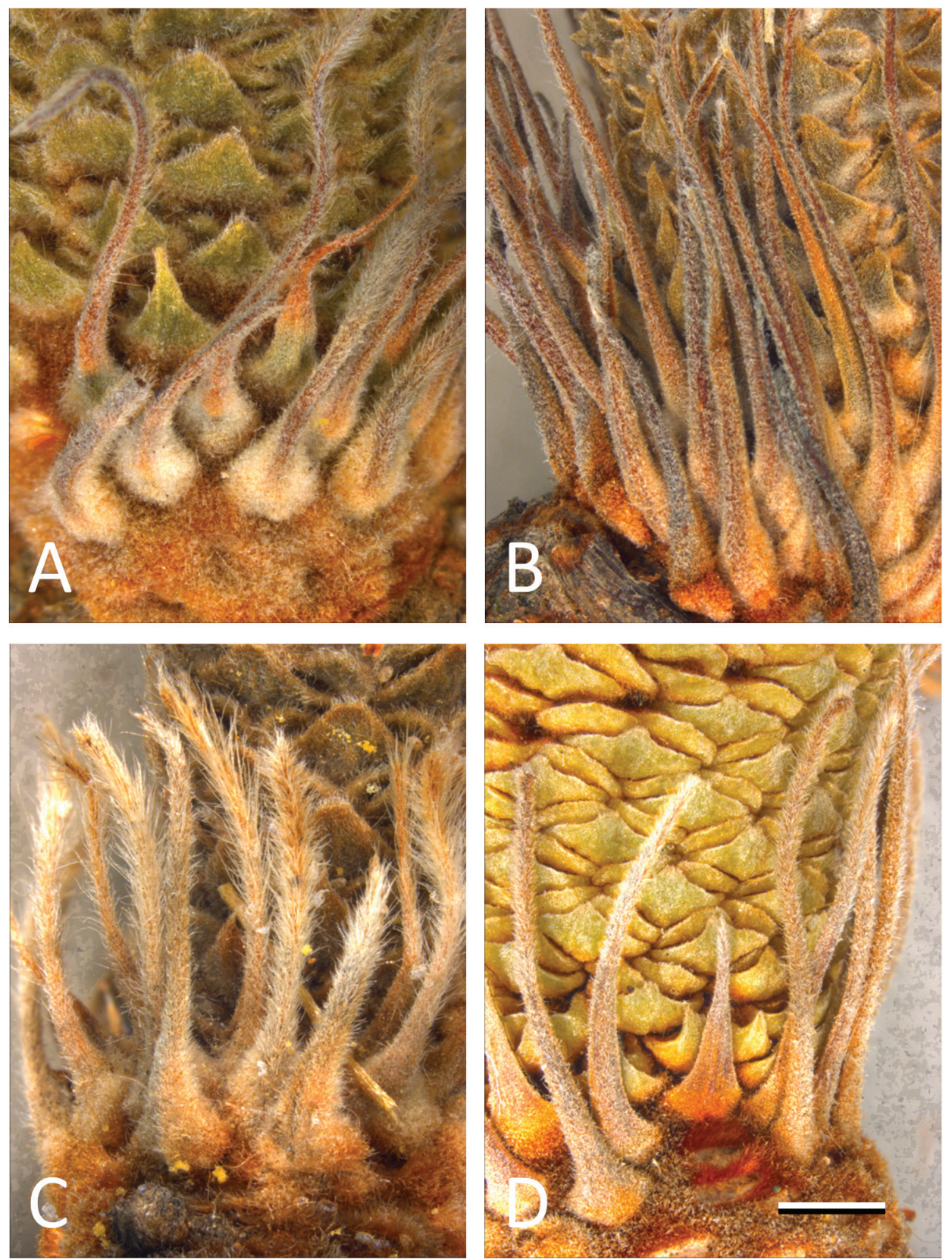

Figure 4. Involucral bracts on young conflorescences in the Banksia spinulosa complex. A B. cunninghamii sensu stricto (M.L. Stimpson 122) B B. spinulosa sensu stricto (M.L. Stimpson 125) C B. neoanglica (M.L. Stimpson 81) D B. collina sensu lato (M.L. Stimpson 25A). Scale bar $=2.5 \mathrm{~mm}$.

acter has been used in the past as an aid to distinguishing B. cunninghamii sensu stricto and the two other 'varieties' recognised at that time (George 1981; Harden 2002). Indeed, this attribute occurs in both $B$. neoanglica and B. cunninghamii sensu 
Table 5. Comparison of some attributes of Banksia neoanglica, B. spinulosa sensu stricto and B. cunninghamii.

\begin{tabular}{c|c|c|c}
\hline Character & B. neoanglica & B. spinulosa & B. cunninghamii \\
\hline Lignotuber & present & present & absent \\
\hline Leaf length & $43-75 \mathrm{~mm}$ & $50-72 \mathrm{~mm}$ & $53-88 \mathrm{~mm}$ \\
\hline Leaf width & $3-4.5 \mathrm{~mm}$ & $1.5-2.5 \mathrm{~mm}$ & $3-4.5 \mathrm{~mm}$ \\
\hline Leaf margins & not recurved & tightly recurved & not recurved \\
\hline Length of inflorescence & $84-119 \mathrm{~mm}$ & $96-144 \mathrm{~mm}$ & $99-152 \mathrm{~mm}$ \\
\hline Common bract keels & single thickened keel & single keel apex & two thin keels \\
\hline Common bract apex & apex rounded & apiculate & apex rounded \\
\hline Number of floral pairs & $12-14(-16)$ pairs & $13-16$ pairs & $12-14$ pairs \\
\hline Perianth colour & orange, or yellow & orange or yellow & pink \\
\hline Style colour prior to anthesis & red $/$ maroon & red $/ \mathrm{maroon}$ & red/maroon \\
\hline Style colour after anthesis & purple/black & purple $/ \mathrm{black}$ & purple/black \\
\hline Circumference of infructescence & $141-160 \mathrm{~mm}$ & $153-159 \mathrm{~mm}$ & $113-125 \mathrm{~mm}$ \\
\hline Length of infructescence & $85-120 \mathrm{~mm}$ & $96-144 \mathrm{~mm}$ & $113-140 \mathrm{~mm}$ \\
\hline
\end{tabular}

stricto. Drying of the specimens in both of these species can cause browning on the abaxial leaf surface. The browning of the abaxial leaf surface should not be used as taxonomic marker or an identification tool.

\section{Future directions}

Disjunct populations in central and northern Queensland currently assigned to $B$. spinulosa var. spinulosa warrant inclusion in a more broadly framed analysis, as do the northern and southern populations of $B$. collina sensu lato and Victorian populations of Banksia cunninghamii sensu stricto. There are also other populations of Banksia that clearly belong with the B. spinulosa group but are as yet unstudied. Further work is needed to enable suitable placement of these populations. Analysis using molecular data, together with expanded use of the novel characters presented here, would likely resolve these long-outstanding taxonomic issues.

\section{Taxonomic treatment}

Banksia neoanglica (A.S.George) Stimpson \& J.J.Bruhl, stat. nov. http://species-id.net/wiki/Banksia_neoanglica

Banksia spinulosa Sm. var. neoanglica A.S.George, Nuytsia 6: 315 (1988).

Type. AUSTRALIA: New South Wales: Northern Tablelands, $900 \mathrm{~m}$ along Waterfall Way towards Ebor from turn-off to New England National Park, 22 May 2011, M.L. Stimpson 180, J.J. Brubl \& I.R. Telford; neotype: NSW; isoneotype: AD, BRI, CANB, CNS, K, MEL, NE, MO, PERTH. Figure 5. 


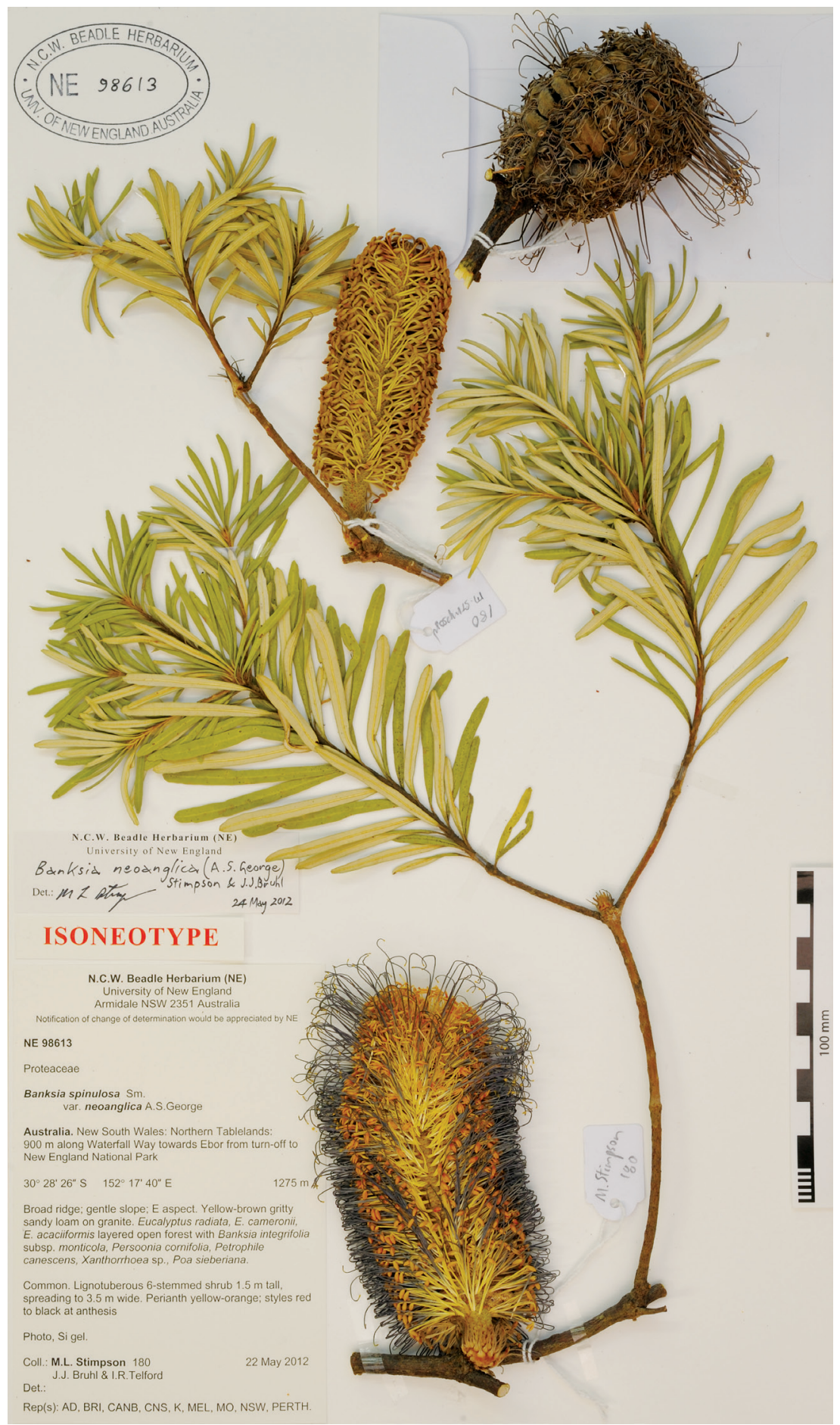

Figure 5. Photograph of the neotype of Banksia spinulosa var. neoanglica A.S.George (M.L. Stimpson 180, J.J. Brubl \& I.R. Telford, NE 98613). 
B. spinulosa Sm. var. cunninghamii (Sieber ex Rchb.) A.S.George, Nuytsia 3: 396 (1981) pro parte, excluding type.

B. cunninghamii Sieber ex Rchb. subsp. A: G.J. Harden in G.J. Harden (ed.), Flora of New South Wales 1: 71 (1991); G.J Harden, D.W. Harden \& D.C. Godden (2000) Proteaceae of New South Wales: 170 (2000); G.J. Harden in G.J. Harden (ed.), Flora of New South Wales 2, edn 2: 86 (2002).

The protologue of $B$. spinulosa var. neoanglica quotes the type:

" $1 \mathrm{~km}$ N of turnoff to New England National Park, Ebor-Armidale road, N.S.W., 6 April 1986, S.C. Clemesha; holo: NSW; iso: CANB, BRI, MEL, PERTH”.

No specimens so labelled have been located in NSW, BRI, CANB or MEL herbaria after repeated searches. Alex George (pers. comm. 2010-2011) could find no specimens in PERTH and he believes it likely that specimens were never distributed. Accordingly, we have nominated a neotype, collected from the same population as the type.

Description. Shrubs with $2-8(-10)$ stems to $2.5 \mathrm{~m}$ from a lignotuber or trees to $7 \mathrm{~m}$ tall. Juvenile leaves: petiole $2-3.8 \mathrm{~mm}$ long; lamina narrowly obovate, $30-66 \mathrm{~mm}$ long, 5-11 mm wide, strongly dentate along full leaf margin, apex bidentate. Adult leaves: petiole 1.8-3.5 mm long; lamina linear, 43-75 mm long, 3-4.5 mm wide, occasionally toothed towards the usually unidentate, occasionally bidentate apex; adaxial surface glabrous, with colour after drying RHS greyed green group 195a-d; abaxial surface felted, colour after drying RHS greyed white group 156a-d. Involucral bracts subulate, thickened at base, $3-15 \mathrm{~mm}$ long, grey-brown pubescent. Conflorescence 84-119 mm long, 70-85 mm diameter at anthesis; floral pairs 12-14(-16) around the circumference of the conflorescence axis. Common bract with a single thickened keel on the abaxial surface that extends from the apex of the bract down to the visible part of the base of the bract, distal margins slightly concave, apex rounded, indumentum villous, lower third of bract uniformly brown and upper two thirds uniformly green (fig. 3A). Perianth 18-23 mm long, pubescent, yellow-orange at maturity but may be green, orange or yellow during developmental stages; limb c. $3.5 \mathrm{~mm}$ long; anthers c. 1 $\mathrm{mm}$ long. Style $25-38 \mathrm{~mm}$ long, apically hooked, colour grading from red to maroon to black just prior to anthesis. Infructescence $85-120 \mathrm{~mm}$ long, $35-45 \mathrm{~mm}$ diam. Seed 15-19 mm long, including wing. Figure 6.

Distribution. Banksia neoanglica occurs on the McPherson Range, just north of the Queensland-New South Wales border, Mt Warning and the eastern edge of the New England Tableland southwards to near Hanging Rock, New South Wales. Figure 7.

Ecology. Grows in sandy soil on granite and acid volcanics, rarely on basalt, in Eucalyptus open forest (Figure 6), woodland and heath at altitudes of $850-1480 \mathrm{~m}$. The species is sympatric with Banksia integrifolia subsp. monticola throughout its range, with $B$. marginata sensu lato on the Gibraltar Range and with B. conferta in the Daves Creek area.

The growth forms that $B$. neoanglica assume appear to be dependent upon the exposure to fire (Whelan and York 1998). In areas where there have been no fires for more than 15 years, such as Lamington National Park, Queensland, and some parts of Gibraltar Range, New South Wales (pers. comm. Justin Kreis 25 May 2010), a singlestemmed habit is found. Here, the lignotuber is present as a stem thickening just above 

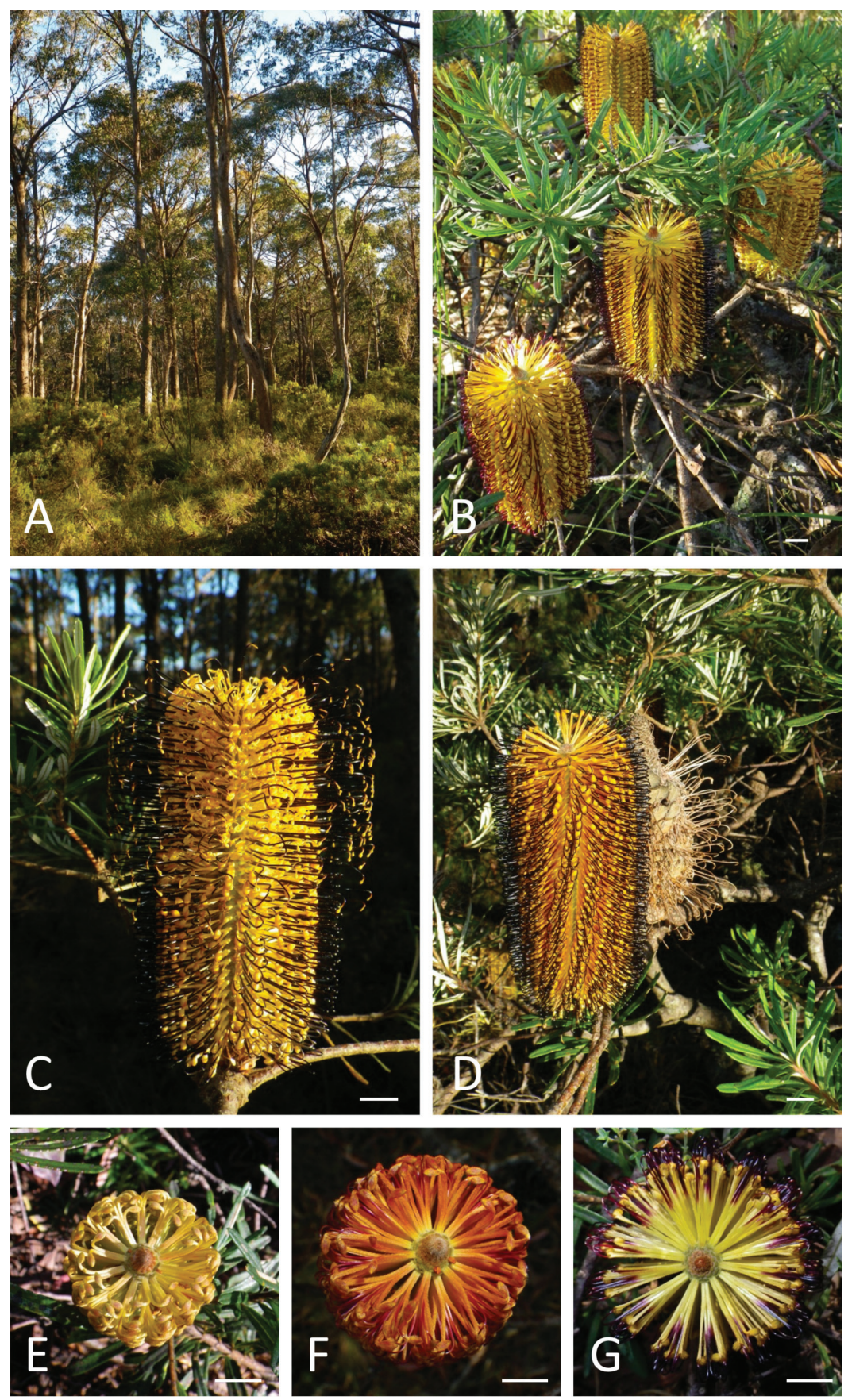

Figure 6. Banksia neoanglica at neotype locality. A Habitat B Conflorescences on shrub C Conflorescence from the neotype collection (M.L. Stimpson 180, J.J. Brubl \& I.R. Telford) showing basipetal development; upper flowers with pollen on pollen presentors D Conflorescence and infructescence with black styles at preanthesis. E-G Apex of conflorescences at successive stages of development exhibiting variation in perianth and style colour. Scale bars $=1 \mathrm{~cm}$. 


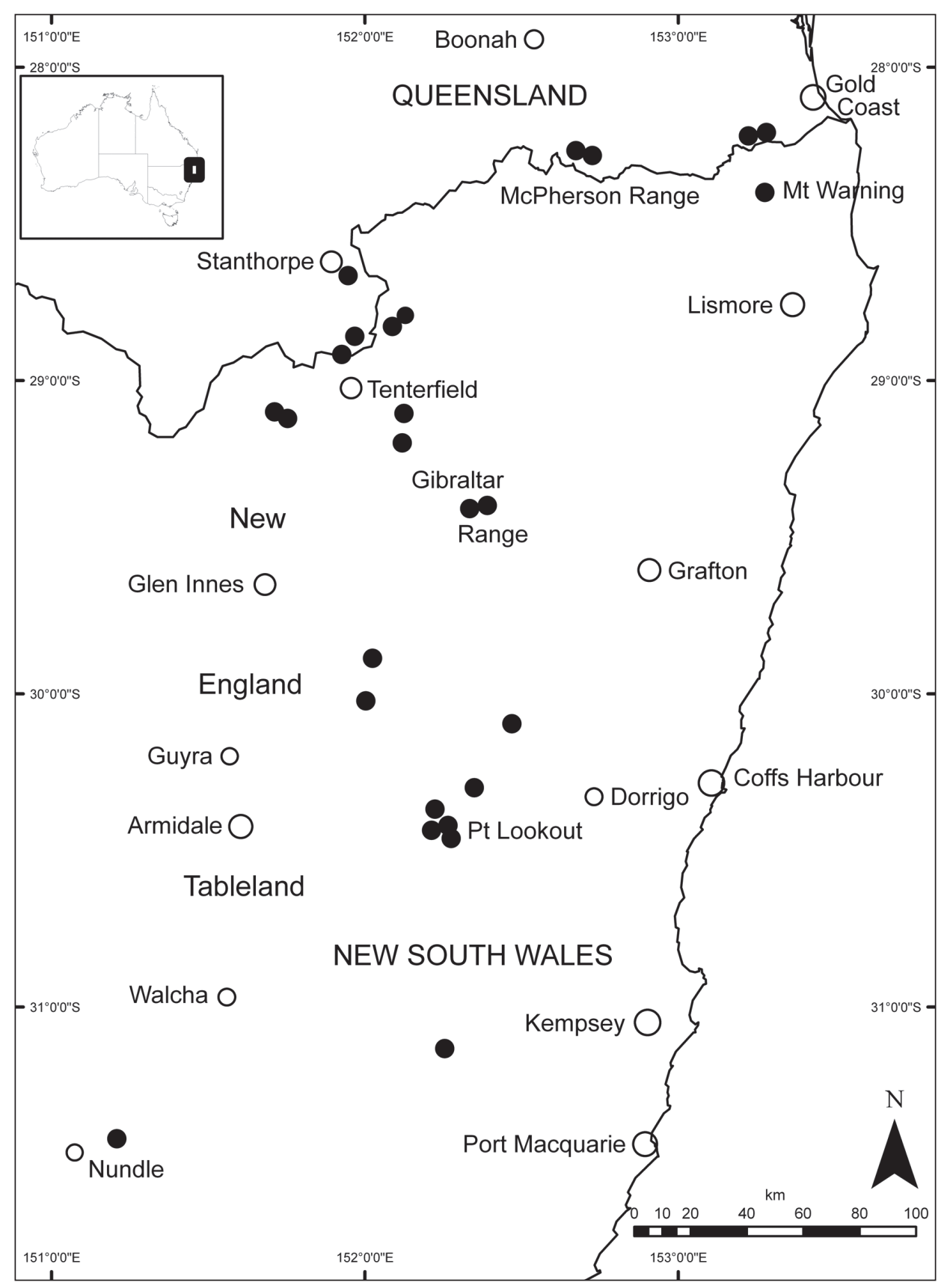

Figure 7. Distribution of Banksia neoanglica (solid black circles). Towns and cities indicated by open circles.

or just below the soil surface, and branchlets may sprout from epicormic buds up to 30 $\mathrm{cm}$ above the ground. This single-stemmed form of B. neoanglica behaves like an obligate seeder with a heavy infructescence load and follicles open spontaneously without 
fire. More commonly the plants are multi-stemmed, with up to $2-8(-10)$ stems from a subterranean lignotuber carry a much lower infructescence load, usually $1-3(-5)$ infructesences per plant. Fire is required to open the follicles.

Conservation status. The species is widespread, often locally common, and is not considered at risk. It is conserved in several reserves: Lamington, Springbrook and Girraween National Parks in Queensland, and Boonoo Boonoo, Gibraltar Range and New England National Parks and Torrington State Conservation Area in New South Wales.

Selected specimens examined. AUSTRALIA. Queensland: Moreton District: McPherson Range, Lamington National Park, Daves Creek track, M.L. Stimpson 79 (BRI, NE, NSW); Darling Downs District: Girraween National Park, track to Mt Norman, 21 Jan. 2009, I.R. Telford 13278 \& J.J. Brubl (NE). New South Wales: North Coast: Mount Warning, 3 Oct. 1939, F.A. Rodway s.n. (NSW); Northern Tablelands: $19 \mathrm{~km}$ E of Deepwater on Miles Shaw Rd, Butterleaf State Forest, J.T. Hunter 3750 \& P.J. Clarke (NE); ); $0.4 \mathrm{~km} \mathrm{~N}$ of Torrington, 19 Nov 1972, J.B. Williams s.n. (NE); Pheasant Mountain, 32 km NE of Guyra, 24 Apr. 1972, H.J. Wissmann s.n. (NE); Mount Chaelundi, E side just below crest, J.T. Hunter 157 \& V.H. Hunter (NE); New England National Park, Banksia Point, M.L. Stimpson 28 (BRI, NE, NSW); NE of Bakers Downfall Hill, Nundle State Forest, J.R. Hosking 1877 (CANB, MEL, NE, NSW).

Phenology. Resting buds start to expand in late January and conflorescences are fully developed by late March with flowering continuing until early July. These times are dependent on climatic conditions.

Breeding system. Extensive experiments conducted between May 1986 and July 1987 found that the New England population of B. neoanglica studied was autogamous (Vaughton 1988).

\section{Acknowledgements}

MLS thanks Leanne and David Rowbotham, Bob and Maureen Anderson for considerable assistance in the location and collection of some coastal populations of Banksia, and Mark and Wendy Alexander for permission to collect on their property. We acknowledge permission from National Parks authorities in New South Wales and Queensland to collect in areas under their administration. Thanks also go to R.D.B. (Wal) Whalley, Ray South, Justin Kries and Alex George for constructive suggestions, and to the directors/curators of herbaria BRI, CANB, CNS, MEL NE, and NSW for specimen data and, where relevant, searching for the original type collection. We acknowledge access to facilities and collections at NE and NSW. Open access to this paper was supported by the Encyclopedia of Life (EOL) Open Access Support Project (EOASP). 


\section{References}

Atlas of Living Australia website at http://www.ala.org.au. Accessed on various occasions through till 24 May 2012

Belbin L, Collins A (2006) PATN. V.3.12. Blatant Fabrications Pty Ltd, Brisbane.

Burbidge N (1960) The phytogeography of the Australian Region. Australian Journal of Botany 8: 75-212. doi: 10.1071/BT9600075

Burrows GE (2008) Syncarpia and Tristaniopsis (Myrtaceae) possess specialised fire-resistant epicormic structures. Australian Journal of Botany 56: 254-264. doi: 10.1071/BT07164

Carlson JE, Holsinger KE (2010) "Natural Selection on Inflorescence Colour Polymorphisms in Wild Protea Populations: The Role of Pollinators, Sees Predators and Intertrait Correlations. American Journal of Botany 97: 934-944. doi: 10.3732/ajb.0900348

Collins K, Collins K, George A (2009) Banksias. 1st edn. Bloomings Books, Melbourne.

Crisp MD, West JG, Linder HP (1999) Biogeography of the Terrestrial Flora. In: Orchar AE (Ed) Flora of Australia. ABRS/CSIRO, Melbourne, 321-367.

Flora of NSW online http://plantnet.rbgsyd.nsw.gov.au/search/simple.htm [accessed 10 November 2010].

George AS (1981) The genus Banksia L.f. (Proteaceae). Nuytsia 3: 239-263.

George AS (1988) New Taxa and Notes on Banksia L.f. (Proteaceae). Nuytsia 6: 309-317.

George AS (1999) Subtrib. Banksiinae, Flora of Australia 17B, CSIRO Publishing, Collingwood, Australia, 175-363.

Grotewold E (2006) The genetics and biochemistry of floral pigments. Annual Review of Plant Biology 57: 761-780. doi: 10.1146/annurev.arplant.57.032905.105248

Harden GJ (2002) Banksia. In: Harden GJ (Ed) Flora of New South Wales 2, edn 2, Royal Botanic Gardens and Domain Trust, Sydney, 82-86.

Johnson LAS, Briggs B (1975) On Proteaceae. The evolution and classification of a southern family. Botanical Journal of The Linnean Society 70: 83-182. doi: 10.1111/j.10958339.1975.tb01644.x

Mast AR, Givnish TJ (2002) Historical biogeography and the origin of stomatal distribution in Banksia and Dryandra (Proteaceae) based on their cpDNA phylogeny. American Journal of Botany 89: 1311-1323. doi: 10.3732/ajb.89.8.1311

Mast AR, Jones EH, Havery SP (2005) An assessment of old and new DNA sequence evidence for the paraphyly of Banksia with respect to Dryandra (Proteaceae). Australian Systematic Botany 18: 75-88. doi: 10.1071/SB04015

Mast AR, Thiele K (2007) The transfer of Dryandra R.Br. to Banksia L.f. (Proteaceae). Australian Systematic Botany 20: 63-71. doi: 10.1071/SB06016

Mibus R, Sedgley M (2000) Early lignotuber formation in Banksia-Investigation into the anatomy of the cotyledonary node of two Banksia species (Proteaceae). Annals of Botany 86: 575-587. doi: 10.1006/anbo.2000.1219

Pickett JW (1997) Layers of Time The Blue Mountains and their Geology. Department of Environment, Climate Change and Water, Sydney.

Plunkett G, Bruhl JJ, Telford IRH (2009) Two new species of Wablenbergia (Campanulaceae). Australian Systematic Botany 22: 319-331. doi: 10.1071/SB09021 
de Queiroz K (2007) Species concepts and species delimitation. Systematic Biology 56: 879886. doi: 10.1080/10635150701701083

Thiele K, Ladiges P (1996) A Cladistic Analysis of Banksia (Proteaceae). Australian Systematic Botany 9: 661-733. doi: 10.1071/SB9960661

Thiers B [continuously updated]. Index Herbariorum: A global directory of public herbaria and associated staff. New York Botanical Garden's Virtual Herbarium. http://sweetgum.nybg.org/ih/

Vaughton G (1988) Pollination and seed set of Banksia spinulosa: evidence of autogamy. Australian Journal of Botany 36: 633-642. doi: 10.1071/BT9880633

Weston PH (2006) Proteaceae. In: Kubitzki (Ed) Families and Genera of Vascular Plants Volume 1X. Springer Verlag, Berlin, 364-404.

Whelan RJ, York J (1998) Post-fire germination of Hakea sericea and Petrophile sessilis after spring burning. Australian Journal of Botany 46: 367-376. doi: 10.1071/BT97075

Wills K, Whalley R, Bruhl J (2000) Systematic studies in Paniaceae (Poaceae) Homopholis and Whalleya gen. et sp. nov. Australian Systematic Botany 13: 437-468. doi: 10.1071/SB99007 Wrigley JW, Fagg M (1989) Banksias, Waratahs and Grevilleas and All Other Plants in the Australian Proteaceae Family. Collins, Sydney.

\section{Appendix I}

Dataset of Banksia spinulosa complex used for phenetic analysis. See Table 1 for OTU codes and Table 2 for character list. (doi: 10.3897/phytokeys.14.3415.app) File format: MS Word (DOC).

Explanation note: The dataset (organised in MS Excel) presented here as a MS Word document, includes 23 characters and 92 individuals (operational taxonomic units = OTUs).

Copyright notice: This dataset is made available under the Open Database License (http://opendatacommons.org/licenses/odbl/1.0/). The Open Database License (ODbL) is a license agreement intended to allow users to freely share, modify, and use this Dataset while maintaining this same freedom for others, provided that the original source and author(s) are credited.

Citation: Stimpson ML, Weston PH, Telford IRH, Bruhl JJ (2012) First instalment in resolution of the Banksia spinulosa complex (Proteaceae): B. neoanglica, a new species supported by phenetic analysis, ecology and geography. PhytoKeys 14: 57-80. doi: 10.3897/phytokeys.57.3415.app 